Pengaruh Model Discovery Learning terhadap Motivasi dan Hasil Belajar Peserta Didik Kelas X MIA SMAN I Gowa (Studi pada Materi Pokok Struktur Atom)

\title{
Pengaruh Model Discovery Learning terhadap Motivasi dan Hasil Belajar Peserta Didik Kelas X MIA SMAN 1 Gowa (Studi pada Materi Pokok Struktur Atom)
}

\section{The Effect of the Discovery Learning Model toward Motivation and Student's Learning Achievement Class X MIA SMAN 1 Goowa (Study on Atomic Structure)}

\author{
1)Annisa Faujiah Miftahul Jannah, ${ }^{2)}$ Alimin, ${ }^{3)}$ Muhammad Jasri Djangi \\ ${ }^{123)}$ Jurusan Kimia Fakultas Matematika dan Ilmu Pengetahuan Alam \\ Universitas Negeri Makassar, Jl. Dg Tata Raya Makassar, Makassar 90224 \\ Email: ditarizkyamalia25@gmail.com
}

\begin{abstract}
ABSTRAK
Penelitian ini merupakan penelitian eksperimen semu (quasi experimental) yang bertujuan untuk mengetahui pengaruh model discovery learning terhadap motivasi dan hasil belajar peserta didik kelas X MIA SMA Negeri 1 Gowa. Desain penelitian yang digunakan adalah "posttestonly control group design". Populasi penelitian ini adalah peserta didik kelas X MIA SMA Negeri 1 Gowa yang terdiri dari tujuh kelas. Teknik pengambilan sampel yang digunakan yaitu class random sampling sehingga sampel penelitian ini adalah kelas X MIA 5 sebagai kelas eksperimen dan kelas X MIA 6 sebagai kelas kontrol dengan jumlah peserta didik masing-masing 36 orang. Variabel bebas pada penelitian ini adalah model discovery learning yaitu motivasi dan hasil belajar. Data motivasi dan hasil belajar yang diperoleh dianalisis dengan menggunakan statistik deskriptif dan statistik inferensial. Pengujian hipotesis untuk pengaruh model discovery learning terhadap motivasi dan hasil belajar peserta didik menggunakan uji-t. Hasil pengujian menunjukkan adanya pengaruh model discovery learning terhadap motivasi hasil belajar peserta didik kelas X MIA SMA Negeri 1 Gowa (Studi pada Materi Pokok Struktur Atom). Hasil penelitian menunjukan bahwa motivasi dan hasil belajar peserta didik mengalami kenaikan namun tidak begitu signifikan yaitu 59,25\% untuk kelas kontrol dan $60,78 \%$ untuk keas eksperimen, sedangkan hasil belajar peserta didik meningkat dari $8,33 \%$ untuk kelas kontrol dan 44,44\% untuk kelas eksperimen.
\end{abstract}

Kata Kunci: Model Discovery Learning, Motivasi, Hasil Belajar

\begin{abstract}
This study is a quasi-experimental research (quasi-experimental), which is aims to determine the effect of discovery learning model approach toward motivation and learning achievement of student's class X MIA SMA Negeri 1 Gowa. The study design used is "posttest-only control group design". These study population were all the students of class X MIA
\end{abstract}


SMA Negeri 1 Gowa which is consists of seven classes. The sampling technique used is class random sampling so that the sample are a class $\mathrm{X}$ MIA 5 as an experimental class and class X MIA 6 as control class with the number of students each 36 peoples. The independent variable in this study is discovery learning model and the dependent variable is motivation and learning achievement of student's. Motivation and learning achievement's data were analyzed using descriptive statistics and inferential statistics. Hypothesis test for effect of discovery learning model approach toward motivation of student's using t-test. The result shown that there is an effect of discovery learning model approach toward motivation and learning achievement of student Class X MIA SMA Negeri 1 Gowa (Study on Stucture Atomic). The results of this research showed that motivation and learning achievement of students increased but not so significant. The average percentage of learning motivation is $59,25 \%$ for control calss increase become $60,78 \%$ for experiment class while learning achievement of students is $8,33 \%$ for control class and $44,44 \%$ fot experiment class.

\section{Keywords: Discovery Learning Model, Motivation, Learning Achievement}

\section{PENDAHULUAN}

Pendidikan merupakan aspek penting bagi perkembangan sumber daya manusia, sebab pendidikan adalah wahana atau salah satu instrumen yang digunakan bukan saja untuk membebaskan manusia dari keterbelakangan, melainkan juga dari kebodohan dan kemiskinan. Berkaitan dengan permasalahan dalam pendidikan, salah satu hal yang menjadi sorotan adalah rendahnya mutu lulusan jenjang SMA pada materi pelajaran sains. Dari beberapa ilmu sains, kimia merupakan salah satu mata pelajaran yang dianggap sulit, ini terjadi karena ilmu kimia yang bersifat abstrak dan kompleks (Depdiknas, 2003).

Penggambaran sesuatu yang abstrak menjadi hal penting pada proses pembelajaran kimia. Guru harus memiliki kreativitas yang tinggi agar pembelajaran kimia di kelas lebih menarik dan bisa diterima secara logis oleh peserta didik agar peserta didik mampu memahami konsep yang diajarkan. Namun yang terjadi saat ini adalah proses pembelajaran masih ada yang menggunakan cara konvensional sehingga konsep abstrak dari mata pelajaran kimia kurang tersampaikan kepada peserta didik hingga berdampak pada menurunnya motivasi dan hasil belajar peserta didik.

Berbicara tentang motivasi belajar, ini sangat berperan dalam keberhasilan peserta didik di sekolah. Sebab melaluinya setiap peserta didik siap melaksanakan aktivitas- aktivitas belajar, sehingga tercapai tujuan belajarnya. Meskipun kegiatan belajar tidak mudah, namun ia akan berusaha melakukan dan menyelesaikan tugasnya sebaik mungkin dengan segala kemampuan yang dimilikinya.

Upaya yang dilakukan untuk meningkatkan motivasi dan hasil belajar peserta didik dalam 
mewujudkan mutu pendidikan yang baik tidak hanya melalui perbaikan kurikulum saja, yang dapat dilakukan adalah menciptakan proses pembelajaran yang menyenangkan dan terkonsep. Hal ini tidak jauh dari peran guru, dimana guru yang professional dituntut harus mampu menampilkan keahlian di depan kelas. Salah satu komponen keahlian itu adalah kemampuan untuk menyampaikan pelajaran kepada peserta didik. Penyampaian pelajaran yang efektif dan efisien, guru perlu mengenal berbagai jenis model pembelajaran.

Berkaitan dengan proses pembelajaran oleh guru kimia di SMA Negeri 1 Gowa. Ditemukan bahwa proses pembelajaran yang biasa digunakan oleh guru adalah metode konvensional dan pemberian tugas yang hanya berpatokan pada buku. Selama ini guru masih mendominasi (teachered centred) selama proses pemebelajaran berlangsung. Namun hal ini hanya memberikan sedikit dampak positif yang tidak begitu signifikan kepada semua peserta didik karena masih adanya peserta didik yang tidak fokus dan masih kurang memahami materi yang dijelaskan. Ditambah lagi tidak semua peserta didik memiliki buku kimia di kelas.

Dari hasil wawancara guru kimia, salah satu materi dalam mata pelajaran kimia yang dianggap sulit oleh peserta didik adalah materi struktur atom hingga mempengaruhi pemahaman peserta didik pada materi lainnya, seperti yang telah kita ketahui bahwa konsep atom terutama struktur atom, merupakan konsep dasar yang harus dikuasai oleh peserta didik untuk memahami konsep-konsep kimia selanjutnya. Sehingga dari analisis peneliti, terdapat peserta didik yang belum mampu memahami dan mengkaitkan konsep dasar ini sehingga sulit pula untuk mengkaitkannya dengan konsep yang lain.

Salah satu model pembelajaran yang dapat meningkatkan minat peserta didik yakni model pembelajaran penemuan atau biasa disebut dengan discovery learning model. Pada model ini, Peserta didik belajar melalui keterlibatan aktif dengan konsep-konsep dan guru bertugas mendorong peserta didik untuk mendapatkan pengalaman dengan melakukan kegiatan yang memungkinkan mereka menemukan konsep sendiri (Slavin dalam Widiadnyana dkk, 2014).

Selain itu, model discovery learning sangat cocok diterapkan pada materi struktur atom yang memiliki banyak konsep yang harus dipahami dengan baik. Melalui pembelajaran discovery, peserta didik dapat memahami konsep dasar materi struktur atom dengan baik sehingga menjadi solusi untuk membuat peserta didik belajar secara aktif dalam rangka melatih dan mengembangkan kemampuannya dalam memahami konsep. Model ini dapat menyebabkan ingatan bertahan lama sampai terinternalisasi pada diri peserta didik dan mampu merangsang peserta didik dalam menganalisis suatu persoalan. Proses pembelajaran yang merangsang peserta didik hal ini terdapat pada salah satu sintaks model pembelajaran discovery learning yaitu stimulus. Pada tahap stimulus peserta didik 
Pengaruh Model Discovery Learning terhadap Motivasi dan Hasil Belajar Peserta Didik Kelas X MIA SMAN I Gowa (Studi pada Materi Pokok Struktur Atom)

dihadapkan dengan sebuah permasalahan sehingga mendorong mereka untuk mengetahui sesuatu dan mencari solusi dari permasalahan yang dihadapkan.

Berdasarkan latar belakang di atas maka akan dilakukan penelitian untuk mengetahui pengaruh model discovery learning terhadap motivasi dan hasil belajar peserta didik kelas $\mathrm{X}$ SMA Negeri 1 Gowa pada materi pokok struktur atom.

\section{METODE PENELITIAN}

Penelitian ini merupakan penelitian eksperimen semu. Variabel bebas dari penelitian ini adalah model discovery learning dan model konvensional sedangkan variabel terikatnya yaitu motivasi dan hasil belajar peserta didik pada struktur atom.

Instrumen yang digunakan dalam penelitian ini adalah instrumen tes hasil belajar yang telah diuji validitasnya dengan menggunakan validitas item dan validitas isi.

Hasil belajar peserta didik yang diperoleh dalam bentuk skor dikonversi ke bentuk nilai dengan rumus:

$$
\text { Nilai }=\frac{\text { skor yang diperoleh peserta didik }}{\text { skor maksimum }} \times 100
$$

Kriteria ketuntasan hasil belajar terlihat pada Tabel 1.

Tabel 1. Kriteria Ketuntasan Belajar Peserta Didik SMAN 1 Gowa

\begin{tabular}{cc} 
Nilai & Kategori \\
\hline$\geq 75$ & Tuntas \\
$<75$ & Tidak Tuntas \\
\hline
\end{tabular}

Analisis statistik inferensial digunakan untuk menguji hipotesis. Sebelum menguji hipotesis terlebih dahulu dilakukan uji prasyarat yaitu uji normalitas dan uji homogenitas.

Hipotesis dari penelitian ini adalah ada pengaruh model discovery learning terhadap motivasi dan hasil belajar peserta didik kelas X MIA SMA Negeri 1 Gowa pada materi pokok struktur atom.

\section{HASIL DAN PEMBAHASAN}

\section{A. Hasil Penelitian}

\section{Analisis Statistik Deskriptif}

Analisis statistik deskriptif memberikan gambaran umum mengenai karakteristik pencapaian hasil belajar peserta didik pada kelompok eksperimen dan kelompok kontrol.

Tabel 2 menunjukkan bahwa bahwa terdapat perbedaan antara motivasi belajar peserta didik untuk kelompok eksperimen dan kelompok kontrol. 
Tabel 2. Nilai Statistik Motivasi Belajar Peserta Didik

\begin{tabular}{lcc}
\hline \multirow{2}{*}{ Statistik } & \multicolumn{2}{c}{ Nilai Statistik } \\
\cline { 2 - 3 } & Kelompok & Kelompok \\
& Eksperimen & 36 \\
Jumlah Sampel & 36 & 64 \\
Nilai Terendah & 69 & 89 \\
Nilai Tertinggi & 94 & 73,83 \\
Nilai Rata-Rata (Mean) & 77,61 & 72,50 \\
Median (Me) & 75,60 & 69,30 \\
Modus (Mo) & 70,38 & 36,50 \\
Varians (S2) & 47,64 & 6,04 \\
Standar Deviasi (S) & 6,90 & \\
\hline
\end{tabular}

Tabel 3. Nilai Statistik Hasil Belajar Peserta Didik

\begin{tabular}{ccc} 
Statistik deskriptif & Nilai Statistik & Kontrol \\
\cline { 2 - 3 } Ukuran Sampel & 36 & 36 \\
Nilai Terendah & 36 & 16 \\
Nilai Tertinggi & 88 & 80 \\
Nilai rata-rata & 60,80 & 42,08 \\
Median & 56,47 & 40,49 \\
Modus & 77,26 & 41,13 \\
Varians & 293,07 & 182,36 \\
Standar Deviasi & 17,11 & 13,50
\end{tabular}

a. Pengujian Prasyarat Analisis

1) Uji Normalitas

Uji normalitas yang digunakan dalam penelitian ini adalah uji chi kuadrat, dengan kriteria data terdistribusi normal jika $\chi^{2}$ hitung $<\chi^{2}$ tabel. Nilai untuk $\chi^{2}$ tabel yang digunakan pada kelas eksperimen dan kelas kontrol adalah pada taraf signifikan $=0,05$ dan derajat kebebasan $(\mathrm{dk})=4$, sehingga diperoleh $\chi_{\text {tabel }}^{2}=9,49$. Untuk kelas eksperimen diperoleh $\chi^{2}$ hitung $=-58,39$ yang artinya nilai $\chi^{2}$ hitung $<\chi_{\text {tabel, }}^{2}$ sehingga dapat disimpulkanłbalíwa data dari kelas eksperimen terdistribusi normal. Selanjutnya untuk kelas kontrol diperoleh $\chi^{2}$ hitung $=-56,57$ yang artinya $\chi^{2}$ hitung $<\chi^{2}$ tabel, sehingga dapat disimpulkan bahwa data dari kelas kontrol terdistribusi normal.

1) Uji Homogenitas

Uji homogenitas digunakan untuk mengetahui apakah kedua 
Pengaruh Model Discovery Learning terhadap Motivasi dan Hasil Belajar Peserta Didik Kelas X MIA SMAN I Gowa (Studi pada Materi Pokok Struktur Atom)

kelompok yan diteliti berasal dari populasi yang homogen atau tidak. Kriteria pengujian homogenitas yang digunakan adalah jika $F_{\text {hitung }}<F_{\text {tabel }}$ maka kedua kelas sampel berasal dari populasi yang homogen. Dari hasil perhitungan pada lampiran A.20 diperoleh nilai $F_{\text {hitung }}=1,302$ dan $F_{\text {tabel }}$ $=1,757$ pada taraf signifikan 0,05 . Karena $F_{\text {hitung }}<F_{\text {tabel }}$ maka dapat disimpulkan bahwa varians pada kelas eksperimen dan kelas kontrol berasal dari populasi yang homogen. Tabel 3 menunjukkan bahwa bahwa terdapat perbedaan antara hasil belajar peserta didik untuk kelompok eksperimen dan kelompok kontrol.

\section{a. Pengujian Prasyarat Analisis}

1) Uji normalitas

Uji normalitas yang digunakan dalam penelitian ini adalah uji chi kuadrat, dengan kriteria data terdistribusi normal jika $\chi^{2}$ hitung $<\chi^{2}$ tabel. Nilai untuk $\chi^{2}$ tabel yang digunakan pada kelas eksperimen dan kelas kontrol adalah pada taraf signifikan $=0,05$ dan derajat kebebasan $(\mathrm{dk})=4$, sehingga diperoleh $\chi_{\text {tabel }}^{2}=9,49$ Dari hasil perhitungan untuk kelas eksperimen diperoleh $\chi^{2}$ hitung $=-70,26$ yang artinya nilai $\chi_{\text {tabel }}>\chi^{2}$ hitung, sehingga dapat disimpulkan bahwa data dari kelas eksperimen terdistribusi normal. Selanjutnya untuk kelas kontrol diperoleh $\chi^{2}{ }_{\text {hitung }}=-214,64$, yang artinya $\chi^{2} \chi_{\text {tabel }}>\chi^{2}$ hitung, sehingga dapat disimpulkan bahwa data dari kelas control terdistribusi normal.

2) Uji Homogenitas

Uji homogenitas digunakan untuk mengetahui apakah kedua kelompok yan diteliti berasal dari populasi yang homogen atau tidak. Kriteria pengujian homogenitas yan digunakan adalah jika $F_{\text {hitung }}<F_{\text {tabel }}$ maka kedua kelas sampel berasal dari populasi yang homogen. Dari hasil perhitungan pada lampiran A.16 diperoleh nilai $F_{\text {hitung }}=1,60$ dan $F_{\text {tabel }}$ $=1,80$ pada taraf signifikan 0,05 . Karena $F_{\text {hitung }}<F_{\text {tabel }}$ maka dapat disimpulkan bahwa varians pada kelas eksperimen dan kelas kontrol berasal dari populasi yang homogen.

Perhitungan uji hipotesis 1 dilakukan untuk mengetahui ada tidaknya pengaruh model discovery learning terhadap motivasi belajar peserta didik. Pada hipotesis pertama diperoleh nilai $t_{\text {hitung }}=2,53$ dan nilai $t_{\text {tabel }}$ pada taraf signifikan 0,05 dan $d k$ $=70$ adalah 1,99 yang berarti, nilai $t_{\text {hitung }}>t_{\text {tabel }}$. Hal ini menunjukkan bahwa $H_{o}$ ditolak dan $H_{1}$ diterima dan disimpulkan bahwa ada pengaruh model discovery learning terhadap motivasi belajar peserta didik SMA Negeri 1 Gowa pada materi pokok Strktur Atom.

Perhitungan uji hipotesis 2 dilakukan untuk mengetahui ada tidaknya pengaruh model Discovery Learning terhadap hasil belajar peserta didik. Dari Lampiran A.20, diperoleh nilai $t_{\text {hitung }}=5,15$ dan nilai $t_{\text {tabel }}$ pada taraf signifikan 0,05 dan $d k=70$ adalah 1,70 yang berarti, nilai thitung $>$ tabel

Hal ini menunjukkan bahwa Ho ditolak dan H1 diterima dan disimpulkan bahwa ada pengaruh model discovery learning terhadap hasil belajar peserta didik SMA Negeri 
Pengaruh Model Discovery Learning terhadap Motivasi dan Hasil Belajar Peserta Didik Kelas X MIA SMAN I Gowa (Studi pada Materi Pokok Struktur Atom)

1 Gowa pada materi pokok Strktur Atom.

\section{B. Pembahasan}

1. Motivasi Belajar

Berdasarkan Tabel 4.3 diperoleh hasil kategori ketuntasan indikator motivasi belajar kelas Eksperimen dan kontrol. Adapun hasil yang di peroleh pada kelas eksperimen, semua indikator berada pada kategori sedang kecuali pada indikator "lebih senang belajar mandiri" yang berada pada kategori rendah. Hal ini menunjukkan bahwa memang pada kelas ekperimen yaitu di kelas X MIA 5 penerapan model discovery learning ini secara umum memberikan efek yang positif terhadap minat belajar peserta didik.

Hal ini menunjukkan bahwa secara umum motivasi dari kedua kelas ini hampir sama walau dengan menggunakan model pembelajaran yang berbeda. Penyebabnya adalah bahwa dalam proses pembelajaran bebepara peserta didik berasumsi bahwa ada kesepian pikiran untuk belajar bagi peserta didik yang kurang pandai, sehngga mereka mengalami kesulitan dalam menghubungkan konsep-kosnep yang tertulis atau lisan sehingga pada gilirannya menimbulkan rasa frustasi.

Ditambah lagi bahwa peserta didik masih belum siap menghadapi proses pembelajaran yang baru dari yang biasa mereka lakukan sebelumnya.

Ketuntasan tiap indikator yang diperoleh dimana kelas eksperimen memiliki rata-rata $60,78 \%$ sedangkan kelas kontrol memiliki rata-rata 59,25\%
Hal ini berarti rata-rata ketuntasan tiap indikator kelas eksperimen lebih tinggi dari pada rata-rata ketuntasan tiap indikator kelas kontrol.

Dari beberapa hasil yang diperoleh dapat disimpulkan bahwa peserta didik pada kelas eksperimen memiliki motivasi belajar yang tinggi dibandingkan kelas control walaupun perubahan itu tidak dirasakan secara signifikan dan perubahannya tidak begitu besar dengan alasan alasan yang telah disebutkan di atas. Hal ini disebabkan adanya model discovery learning yang diterapkan dimana peserta didik memperoleh suasana belajar yang belum peserta didik dapatkan sebelumnya yang memacu peserta didik lebih termotivasi dalam belajar.

Dari hasil analisis statistik inferensial, dinyatakan bahwa data dari kelas eksperimen dan kontrol berasal dari populasi yang terdistribusi normal dan homogen, sehingga pengujian hipotesis dengan uji-t dapat dilanjutkan. Hasil pengujian tersebut memberikan kesimpulan bahwa $\mathrm{H}_{0}$ ditolak dan $\mathrm{H}_{1}$ diterima, artinya dengan adanya model Didcovery Learning, memberikan pengaruh positif terhadap motivasi belajar peserta didik pada SMA Negeri 1 Gowa kelas X MIA.

\section{Hasil Belajar}

Hasil analisis deskriptif menunjukkan ada perbedaan hasil belajar antara kelas eksperimen I dan kelas eksperimen II, sebagaimana ditunjukkan pada Tabel 1. Berdasarkan Tabel 1, diketahui bahwa nilai rata-rata 
Pengaruh Model Discovery Learning terhadap Motivasi dan Hasil Belajar Peserta Didik Kelas X MIA SMAN I Gowa (Studi pada Materi Pokok Struktur Atom)

hasil belajar peserta didik kelas eksperimen I $(70,97)$ lebih tinggi dibandingkan nilai rata-rata hasil belajar peserta didik kelas eksperimen II $(63,31)$.

Nilai rata-rata posttest untuk hasil belajar pada kelas eksperimen yaitu 60,80 sedangkan pada kelas kontrol yaitu 42,08.

Jumlah peserta didik yang tuntas pada kelas eksperimen dan kelas kontrol berbeda. Persentase ketuntasan untuk kelas eksperimen dan kontrol sebesar 44,44\% dan 8,33\% (Tabel 4.5).

Penggunaan model discovery learning memberikan hasil belajar yang lebih baik dibandingkan dengan model pembelajaran langsung disebabkan karena selama proses pembelajaran berlangsung mampu melibatkan peserta didik secara aktif dalam kelas walaupun perubahan yang terjadi tidak begitu signifikan (sesuai hasil persentase keaktifan peserta didik pada Lampiran C.17). Adapun Kurangnya keaktifan peserta didik pada aspek tersebut karena sebagian peserta didik masih kurang memiliki rasa percaya diri untuk mengemukakan pendapat mereka di depan kelas, peserta didik kurang berani jika saja jawaban yang mereka ajukan salah dan tidak sesuai dengan yang diharapkan. Namun, secara umum dari pertemuan I sampai III terlihat peningkatan aktivitas dari semua indikator aktivitas yang diamati.

Berdasarkan pengujian analisis prasyarat (uji normalitas dan uji homogenitas), dinyatakan bahwa data dari kelas eksperimen dan kontrol berasal dari populasi yang terdistribusi normal dan kedua kelompok berasal dari varians yang homogen, sehingga pengujian hipotesis dapat dilakukan dengan menggunakan uji t. Dengan nilai thitung 5,15 dan $t_{\text {tabel }} 1,70$ berarti hipotesis yang dajukan diterima. Dengan demikian, dapat disimpulkan bahwa model discovery learning berpengaruh positif terhadap hasil belajar peserta didik kelas X MIA SMA Negeri 1 Gowa pada materi pokok struktur atom.

Berdasarkan pengujian hipotesis yang dilakukan, dapat dikatakan bahwa model discovery learning berpengaruh positif terhadap hasil belajar peserta didik kelas X MIA SMA Negeri 1 Gowa pada materi pokok struktur atom.

Walaupun secara umum terdapat perubahan positif terhadap peserta didik dalam meningkatkan motivasi dan hasil belajarnya namun perubahan yang tidak begitu dignifikan yang dihasilkan, dimana motivasi belajar pesera didik secara umum tinggi namun hasil belajarnya tidak begitu memuaskan, ini dikarenakan beberapa faktor selain diatas seperti kesiapan guru dalam mengarahkan proses pembelajaran tidak maksimal sehingga berpengaruh juga terhadap pemahaman peserta didik, ditambah lagi model pembelajaran yang baru dilakukan sehIngga peserta didik harus beradaptasi dengan pembelajaran baru tersebut dalam waktu singkat.

\section{KESIMPULAN DAN SARAN}

\section{A. Kesimpulan}

Berdasarkan hasil analisis data dan pembahasan maka dapat disimpulkan bahwa:

1. Ada pengaruh positif model discovery learning terhadap 
Pengaruh Model Discovery Learning terhadap Motivasi dan Hasil Belajar Peserta Didik Kelas X MIA SMAN I Gowa (Studi pada Materi Pokok Struktur Atom)

motivasi belajar peserta didik kelas X MIA SMA Negeri 1 Gowa pada materi pokok struktur atom.

2. Ada pengaruh positif model discovery learning terhadap hasil belajar peserta didik kelas X MIA SMA Negeri 1 Gowa pada materi pokok struktur atom.

\section{B. Saran}

Berdasarkan hasil yang diperoleh dari penelitian ini, maka dikemukakan saran-saran sebagai berikut :

1. Guru diharapkan dapat mengatur waktu dengan baik ketika ingin menggunakan model discovery learning ini, karena dibutuhkan pengelolaan waktu yang lebih lama dari pembelajaran umumnya.

2. Guru diharapkan terlebih dahulu menjelaskan kepada peserta didik mengenai model pembelajaran yang digunakan kepada peserta didik karena peserta didik belum terbiasa dengan penggunaan model discovery learning

3. Penelitian ini diharapkan dapat menjadi salah satu alternatif bagi guru yang dapat digunakan dalam proses pembelajaran.

\section{DAFTAR PUSTAKA}

Aritonang, K.T. 2008. Minat dan Motivasi dalam Meningkatkan Hasil Belajar Siswa. Jurnal Pendidikan Penabur. No.7

Darmadi, K. 2017. Pengembangan Model dan Metode

Pembelajaran dalam Dinamika Belajar

Siswa. Yogyakarta: CV Budi Utama.
Dimyati dan Mudjiono. 2006. Belajar dan Pembelajaran. Jakarta: Rineka Cipta.

Djamarah, S.B. dan Aswan, Z. 2010. Strategi Belajar Mengajar. Jakarta: Rineka Cipta.

Haryati, M. 2007. Model dan Teknik Penilaian pada Tingkat Satuan Pendidikan. Jakarta: Gaung Persada Press.

Hamdu, Ghullam dan Lisa Agustina. 2014. Pengauh Motivasi Belajar Siswa Terhadap Prestasi Belajar IPA di Sekolah Dasar. Jurnal Penelitian Pendidikan. Vol.12. No.1

Hamalik,O. 2001. Proses belajar Mengajar. Jakarta: Bumi Aksara

Irmi. 2018. Penerapan Model Discovery Learning Melalui Game Gets Lucky pada Materi Hidrokarbon dan Minyak Bumi dalam Peningkatan Aktivitas dan Hasil Belajar

Siswa Kelas XI MIPA 2 SMAN Unggul Aceh Timur. (JIPI) Jurnal IPA dan Pembelajaran IPA. 2 (1).

Imaduddin, Roni. 2016. Media Pembelajaran Buku Interaktif Pengenalan Resistoruntuk Mata Pelajaran Teknik Listrik di SMK Muda Patria Kalasan. Skripsi: Universitas Negeri Yogyakarta

Komalasari, K. 2013. Pembelajaran Kontekstual Konsep dan Aplikasi. Bandung: Retika Aditama.

Kurinasih, I., dan Berlin, S. 2014. Sukses Mengimplementasikan Kurikulum 2013. Jakarta: Kata Pena. 
Pengaruh Model Discovery Learning terhadap Motivasi dan Hasil Belajar Peserta Didik Kelas X MIA SMAN I Gowa (Studi pada Materi Pokok Struktur Atom)

Muchtaridi. 2016. Kimia I SMA Kelas X. Jakarta: Yudhistira Mariyaningsih, Nining dan Mustina

Hidayati. 2018. Teori dan Praktik Berbagai Model dan Metode Pembelajaran Menerapkan Inovasi Pembelajaran di KelasKelas Inspiratif. Surakarta: CV Kakata Group.

Mutmainna dan Ferawati. 2015. Komparasi Hasil Belajar Fisika Melalui Metode Discovery Learning dan Assigment and Recitation. Jurnal Pendidikan Fisika. Vol.3 No.1.

Mappeasse, Muh. Yusuf. 2009. Pengaruh Cara dan Motivasi Belajar Terhadap Hasil Belajar Programmable Logic Controller (PLC) Siswa Kelas III Jurusan Listrik SMK Negeri 5 Makassar. Jurnal Medtek. Vol 1 No. 2. Malang: Universitas Negeri Malang

Peraturan Menteri Pendidikan dan Kebudayaan Republik Indonesia Nomor 22 Tahun 2016 Tentang Standar Proses Pendidikan Dasar dan Menangah. Rasyidin, dkk. 2009. Penilaian Hasil belajar. Bandung: CV Wacana Prima.

Retno, dkk. 2008. Penggunaan Metode Pembelajaran Kooperatif tai (Team Assisted Individualization) dilengkapi Modul dan Penilaian Portofolio Untuk Meningkatkan Prestasi Belajar Penentuan $\mathrm{dH}$ Reaksi Siswa SMA Kelas XI Semester 1. Jurnal Varia Pendidikan Vol 20 No.1.
Sardiman, A. M. 2004. Interaksi dan Motivasi Belajar Mengajar. PT Raja Grafindo Persada. Jakarta.

Sudjana, N. 1989. Penialian Hasil Proses Belajar Megajar. Bandung: PT Remaja Rosdakarya.

Syarifuddin K. 2018. Pendidikan Agama Islam dan Budi Pekerti. Yogyakarta: CV Budi Utama.

Syah. 2004. Psikologi Pendidikan dengan Pendekatan Baru. Bandung: PT Remaja Rosdakarya.

Suardin. 2016. Penerapan Metode Discovery Learning pada Materi Sistem Pencernaan untuk Meningkatkan Hasil Belajar Siswa Kelas VIII SMP Negeri 2 Labuan. Jurnal Kratif Tadulako Online. 4 (3).

Sudarmo, Unggul. 2013. Kimia untuk SMA/MA Kelas X. Jakarta : Erlangga

Widiadnyana dkk. 2014. Pengaruh Model Discovery Learning Terhadap

Pemahaman Konsep IPA dan Sikap Ilmiah Siswa SMP. eJournal Program Pascasarjana Universitas Pendidikan Ganesha vol 4 No. 1.

Widiyowati, Iis Intan. 2014. Hubungan Pemahaman Konsep Struktur Atom Dan Sistem Periodik Unsur Dengan Hasil Belajar Kimia Pada Pokok Bahasan Ikatan Kimia. Pancaran Vol 3 No 4. 